\title{
Stem cells and exosomes: promising candidates for necrotizing enterocolitis therapy
}

\author{
Ruijie Zeng ${ }^{1,2+}$, Jinghua Wang ${ }^{3 \dagger}$, Zewei Zhuo ${ }^{1}$, Yujun Luo ${ }^{1}$, Weihong Sha ${ }^{1 *}$ and Hao Chen ${ }^{1 *}$ (D
}

\begin{abstract}
Necrotizing enterocolitis (NEC) is a devastating disease predominately affecting neonates. Despite therapeutic advances, NEC remains the leading cause of mortality due to gastrointestinal conditions in neonates. Stem cells have been exploited in various diseases, and the application of different types of stem cells in the NEC therapy is explored in the past decade. However, stem cell transplantation possesses several deficiencies, and exosomes are considered potent alternatives. Exosomes, especially those derived from stem cells and breast milk, demonstrate beneficial effects for NEC both in vivo and in vitro and emerge as promising options for clinical practice. In this review, the function and therapeutic effects of stem cells and exosomes for NEC are investigated and summarized, which provide insights for the development and application of novel therapeutic strategies in pediatric diseases. Further elucidation of mechanisms, improvement in preparation, bioengineering, and administration, as well as rigorous clinical trials are warranted.
\end{abstract}

Keywords: Stem cell, Exosome, Breast milk, Necrotizing enterocolitis

\section{Introduction}

Necrotizing enterocolitis, a devastating disease predominately affecting neonates, has attracted wide attention of researchers for decades. As a leading cause of death among gastrointestinal diseases in neonates, NEC occurs in 1-3 per 1000 live births every year in the USA [1]. The mortality of infants suffering from NEC is estimated as 20 to $40 \%$, while infants with less gestational ages demonstrate higher mortality [2]. In addition, the mortality of infants requiring NEC surgery can be up to $50 \%$ [2]. Despite treatment advances, the morbidity and mortality remain high. Short-term complications of NEC include short bowel syndrome, intestinal dysmotility, strictures, perforation, and sepsis, while intestinal failure,

\footnotetext{
* Correspondence: shaweihong@gdph.org.cn; chenhao@gdph.org.cn

${ }^{\dagger}$ Ruijie Zeng and Jinghua Wang contributed equally to this work.

'Department of Gastroenterology, Guangdong Provincial People's Hospital, Guangdong Academy of Medical Sciences, Guangzhou 510080, China Full list of author information is available at the end of the article
}

neurodevelopmental delay, and failure to thrive can be developed in the long term.

The etiology of NEC is multifactorial, and several risk factors that predispose neonates to NEC are identified. The best-known risk factors for NEC are low gestational age and low birth weight. In addition, formula feeding and prolonged parenteral feeding increase the risk of NEC. Congenital heart diseases, polycythemia, and respiratory distress are also reported as risk factors for NEC. Moreover, maternal conditions, including pregnancy-induced hypertension, preeclampsia, smoking, gestational diabetes, and chorioamnionitis, are reported to induce NEC [3].

For pathogenesis, the susceptibility and hyperreactivity of preterm gut, which predispose the infantile intestine to altered immune response, vascular injury, and dysregulated microbiota, are the root causes contributing to NEC [4]. Intestinal mucosal hypoxia and impairment of the intestinal microcirculation are 
correlated with the development of NEC [5]. The pathoimmunological changes of NEC include deficiency in anti-inflammatory mediators and increases in proinflammatory mediators $[6,7]$. The anti-inflammatory cytokine interleukin (IL)-37 and its receptor, as well as protective innate lymphoid cells are deficient in NEC, while pro-inflammatory innate lymphoid cells are increased [7]. Alterations of IL-37 also mediate the modulation of toll-like receptor (TLR) expression. The innate immune receptor TLR4 that specifically recognizes bacterial lipopolysaccharide (LPS) is upregulated in premature infant intestine and activates innate immunity [8]. TLR4 activation promotes inflammation by enhancing the activity of pro-inflammatory cytokines and signals, leading to the NEC development [7, 8]. Defective Wnt signaling in intestinal stem cells (ISCs) and impaired intestinal regeneration also contribute to NEC development [9]. However, specific mechanisms directly lead to NEC remain largely unknown. The lack of understanding of the pathogenetic mechanisms in depth restricts the development of NEC-specific treatment modalities.

The mainstays of NEC treatment include cessation of enteral feedings, gastric decompression, antibiotics, parenteral nutrition, and surgery, and they are non-specific. Despite therapeutic advances, severe NEC (Bell stage III) is often considered incurable. Therefore, novel treatment modalities are urgently needed for NEC therapy. Emerging strategies for the treatment of neonates with NEC have been explored by researchers in recent years, in which stem cells and exosomes demonstrate promising effects and potential clinical application.

In this review, the applications of stem cells and exosomes for the NEC therapy are investigated. Our review principally aims to integrate current studies on NEC therapy by stem cells and exosomes and therefore provides insights for the development and application of novel therapeutic strategies for NEC.

\section{Stem cells and extracellular vesicles Biology and function of stem cells}

Stem cells are defined as unspecialized cells possessing the capacity of self-renewal and generation of multiple mature cell types [10]. Basically, stem cells can be classified based on origins or differentiation potential (Table 1). On the one hand, a simple and convenient way to categorize stem cells is to divide them according to their origins, for example, embryonic stem cell (ESC) and adult stem cell (ASC). Induced pluripotent stem cells (iPSCs) have emerged in recent years as the third type of stem cells. Compared to ESCs, ASCs are most successfully applied in human therapy, with the advantages of abundant resources, less ethical concerns and lower risk of rejection [11]. Further definition of ASCs can be based on their sources. On the other hand, the capacity of stem cells to differentiate into distinct cell types varies, and therefore stem cells can also be classified into unipotent, oligopotent, multipotent, pluripotent, and totipotent stem cells. ASCs are regarded as multipotent cells, indicating that they are able to differentiate into multiple cell types but restricted to certain lineages.

Intestinal epithelial cell lineages can be harmed by stressors such as ischemia, hypoxia, and hypothermia, especially in NEC, and ISCs are responsible to facilitate the repair and regeneration of intestinal epithelial cell lineages harmed by stressors in NEC [12]. Currently, two types of stem cells have been identified in small intestinal crypts: crypt base columnar cells and " +4 " cells, which are cycling and quiescent, respectively [13]. CBC cells mainly express LGR5 and prominin -1 , while " +4 " cells principally express Bmi1 [13]. The characterization of LGR5 as a marker for mitotically active ISCs, which exhibit sensitivity to canonical Wnt modulation and contribute to homeostatic regeneration, allows researchers to study the function of ISCs in NEC.

Table 1 Classifications of stem cells

\begin{tabular}{|c|c|c|c|}
\hline Classification & $\begin{array}{l}\text { Stem cell } \\
\text { types }\end{array}$ & Definition & Examples \\
\hline \multirow[t]{3}{*}{ Origin } & Embryonic & Stem cells derived from the early stages of embryos & / \\
\hline & Adult & $\begin{array}{l}\text { Stem cells identified throughout the body that divide to replenish dying cells and } \\
\text { regenerate damaged tissues }\end{array}$ & \\
\hline & $\begin{array}{l}\text { Induced } \\
\text { pluripotent }\end{array}$ & $\begin{array}{l}\text { Stem cells derived from adult cells by being reprogrammed to embryonic stem cell-like } \\
\text { states }\end{array}$ & \\
\hline \multirow[t]{5}{*}{$\begin{array}{l}\text { Differentiation } \\
\text { potential }\end{array}$} & Unipotent & Stem cells with the capacity to differentiate into only one specific cell type & $\begin{array}{l}\text { Muscle satellite } \\
\text { cells }\end{array}$ \\
\hline & Oligopotent & Stem cells with the capacity to differentiate into only a few cell types & $\begin{array}{l}\text { Lymphoid stem } \\
\text { cells }\end{array}$ \\
\hline & Multipotent & Stem cells with the capacity to differentiate into multiple cell types & Adult stem cells \\
\hline & Pluripotent & Stem cells with the capacity to differentiate into nearly all cell types & $\begin{array}{l}\text { Embryonic stem } \\
\text { cells }\end{array}$ \\
\hline & Totipotent & Stem cells with the capacity to differentiate into all cell types and a functional organism & Zygotes \\
\hline
\end{tabular}


The reduced proliferation of ISCs contributes NEC exacerbation, which indicates that maintaining the homeostasis of intestine and protecting ISCs within the newborn intestine are essential [9]. Heparin-binding epidermal growth factor (EGF)-like growth factor (HBEGF), which was first identified in the conditioned medium of macrophage-like cells, can protect ISCs from in vitro hypoxic injury and in vivo NEC model [14]. In addition, all-trans retinoic acid, a vitamin A derivative, restores $\mathrm{T}$ cell balance, protects ISC pool, and further prevents the development of NEC [15]. Moreover, exogenous provision of Wnt can activate ISCs to promote the proliferation, differentiation, and repair of injured intestinal epithelium in experimental NEC, which indicates that $\mathrm{Wnt} / \beta$-catenin signaling is the upstream pathway for ISC-modulated intestinal regeneration [9]. Although ISCs are originated from intestine, hurdles exist for ISC transplantation, which include incomplete understanding of human ISCs/progenitor and niche cells, difficult expansion in vitro, and insufficient methods to enrich ISC subtypes as well as undeveloped methods to integrate ISCs into existing intestinal mucosa [16]. Consequently, current studies mainly focus on the transplantation of other types of ASCs. The study of stem cell transplantation on inflammatory bowel disease is most advanced among all intestinal diseases. Guided by the successful experimental and clinical application of stem cells in inflammatory bowel diseases [17], which shares similar features with NEC, the study of stem cells on NEC is emerging in recent years.

In addition to the basic ability of regeneration and replacement, stem cells also act by paracrine actions. Under certain conditions, a variety of paracrine factors can be secreted by stem cells, which exert different biological effects such as anti-inflammation, anti-apoptosis, promoting proliferation, and enhancing migration [18].

\section{Biology and function of extracellular vesicles}

Extracellular vesicles (EVs) are nanosized, cell-derived membrane-bound vesicles functioning as a means of cell to cell communication. A wide spectrum of cells, not limited to stem cells, can release EVs, which contain biological materials including DNA, RNA, lipids, and proteins, into biological fluids. Apoptotic bodies, microvesicles, and exosomes are the three main types of EVs. Apoptotic bodies $(0.5-2.0 \mu \mathrm{m})$ are released as products of cell apoptosis. Microvesicles $(0.1-1.0 \mu \mathrm{m})$ are vesicular structures budding directly from the plasma membrane. Exosomes $(40-120 \mathrm{~nm})$ are smaller vesicles formed by the fusion of multivesicular bodies and the plasma membrane [19]. Among the three types of EVs, exosomes are most studied and best characterized in various diseases.
Exosomes are extensively explored for their therapeutic potential in fundamental research, demonstrating novel capacities in treating intractable conditions. Several clinical trials have reported the application of exosomes, and most of them are studies for patients with cancers [20]. To date, there is no registered clinical trial of stem cells or exosomes for NEC. Our integration of current findings on fundamental and preclinical research might evoke the application of exosomes for NEC therapy clinically.

\section{Stem cells in necrotizing enterocolitis therapy (Table 2)}

In the past two decades, stem cell therapy has become a heated topic for researchers and promising results are illustrated. The study of stem cells on NEC emerged approximately a decade ago, with a dramatic increase in number in the last few years.

\section{Mesenchymal stem cells (MSCs) \\ Bone marrow-derived mesenchymal stem cells}

MSCs are ASCs isolated from multiple stromal tissues including bone marrow, umbilical cord, adipose tissue, and others. Bone marrow-derived mesenchymal stem cells (BM-MSCs), as indicated by its name, are MSCs derived from bone marrow and are capable to differentiate into multiple cell types. In rat models of NEC, intraperitoneal injection of BM-MSCs reduces NEC incidences and improves the body weight and clinical sickness score, as well as the histopathological changes by homing to the injured sites [21, 24]. Referring to the means of BM-MSC administration in NEC, intraperitoneal injection was first reported. However, compared to intraperitoneal administration, the intravenous administration of BM-MSCs at the same dose in rats might more significantly increase stem cell engraftments into intestines, with a lower incidence of NEC and better improvement in gut barrier function [14].

In order to enhance the therapeutic effect of BMMSCs, co-administration with biologically active molecules may achieve synergistic effects. HB-EGF, which is secreted by macrophage-like cells and identified to protect ISCs, has been successfully used in NEC treatment. The combination of HB-EGF and BM-MSC administration intravenously in rat models of NEC leads to the best improvement in intestinal barrier function and survival compared to HB-EGF or BM-MSC administrated alone [14].

BM-MSCs are also proved as tremendous storage of cytokines and growth factors. The secretion of IL-6, VEGF, and hepatocyte growth factor (HGF), which increase the viability and proliferation of intestinal cells, by BM-MSCs under hypoxia mimicking NEC has been confirmed [33]. However, direct application of BM-MSC- 
Table 2 Functions and applications of stem cells in NEC

\begin{tabular}{|c|c|c|c|c|c|c|}
\hline $\begin{array}{l}\text { Stem } \\
\text { cell } \\
\text { type }\end{array}$ & $\begin{array}{l}\text { Stem cell } \\
\text { origin }\end{array}$ & $\begin{array}{l}\text { Stem cell } \\
\text { administration }\end{array}$ & Model & Modeling method ${ }^{\mathrm{a}}$ & Main findings & Mechanism Reference \\
\hline
\end{tabular}

\section{Bone marrow-derived stem cell (BM-MSC)}

BM- Human

MSC

Intraperitoneal

injection

$\begin{array}{ll}\text { BM- } & \text { Mouse } \\ \text { MSC homozygotes }\end{array}$

Intraperitoneal

injection

Intravenous

injection

\section{itro}

min

In vivo

\begin{tabular}{l}
${ }^{\circ} \mathrm{C}, 10 \mathrm{~min}$, bid until the end of \\
\hline
\end{tabular} experiment)

Rat pups with formula feeding, hypoxia-hyperoxia $\left(100 \% \mathrm{CO}_{2} / 97 \%\right.$ $\mathrm{O}_{2}, 10 \mathrm{~min} / 5 \mathrm{~min}$, bid for 3 days) and hypothermia $\left(4^{\circ} \mathrm{C}, 5 \mathrm{~min}\right.$, bid for 3 days)

BM-MSCs administrated by

intraperitoneal injection improve

pathological changes of the

neonatal NEC rat model.

BM-MSCs injected rats show

significant weight gains and clinical

sickness score improvement.

BM-MSC proliferation, migration,

and survival are increased by $\mathrm{HB}$ -

EGF.

BM-MSCs administrated

intravenously have increased

engraftment into intestine

compared to BM-MSCs adminis-

trated intraperitoneally.

BM-MSCs and HB-EGF co-

administration significantly lowers

the incidence of NEC and improves

gut barrier function as well as

survival.

BM- Human

Intravenous

In vivo

Preterm fetal sheep with umbilical cord occlusion (25 min)

BM-MSCs administrated

intravenously do not relieve

hypoxia-ischemia induced adverse

intestinal events, which may be associated with NEC.

BM- Adult rat

Intraperitoneal In vivo Rat pups with formula, hypoxia (100\% $\mathrm{N}_{2}, 1.5 \mathrm{~min}$, tid for 4 days) and hypothermia $\left(4^{\circ} \mathrm{C}, 10 \mathrm{~min}\right.$, tid for 4 days)

BM-MSC, AF-MSC, amniotic fluidderived NSC and enteric NSC treatments all show a significant decrease in intestinal permeability and improved gut barrier function compared to the control group. There is no significant difference in intestinal permeability or gut barrier function among the four treatment groups.

BM- Adult rat MSC

ntraperitoneal injection
In vivo Rat pups with formula, hypoxia $\left(100 \% \mathrm{~N}_{2}, 1.5 \mathrm{~min}\right.$, tid for 4 days) and hypothermia $\left(4^{\circ} \mathrm{C}, 10 \mathrm{~min}\right.$, tid for 4 days)

BM- Adult rat MSC
Intraperitoneal injection (conditioned medium) $\ln$ vitro In vivo
Rat pups with hyperosmolar formula, hypoxia $\left(5 \% \mathrm{O}_{2}, 95 \% \mathrm{~N}_{2}\right.$ , tid for 2 days) and LPS (4 $\mathrm{mg} / \mathrm{kg}$, qd for 2 days)

\section{Amniotic fluid-derived mesenchymal stem cell (AF-MSC)}

AF- E14 rat

MSC
Intraperitonea injection
In vivo Rat pups with hyperosmolar formula, hypoxia $\left(5 \% \mathrm{O}_{2}, 95 \% \mathrm{~N}_{2}\right.$ $10 \mathrm{~min}$, tid for 2 days) and LPS (4 $\mathrm{mg} / \mathrm{kg}$, qd for 2 days)
BM-MSC, AF-MSC, amniotic fluidderived NSC, and enteric NSC treatments all show significant reductions in NEC incidence compared to the control group.

There is no significant difference in incidence among the four treatment groups.

Condition medium of PHD2PHD2-NFsilenced BM-MSCs repairs the intes- KB-IGF-1, tinal damage and improves the sur- TGF- $\beta 2$ vival of NEC rats.

BM-MSCs' paracrine effect is enhanced by PHD-2 silencing. PHD-2 silencing activates NF-KB and promotes IGF-1 as well as TGF$\beta 2$ secretion in BM-MSCs.

BM-MSCs lack beneficial effects on survival.

Stromal cells

AF-MSCs improve survival and increase the repair of injured intestine in NEC via a COX-2 expressing COX-2 dependent mechanism. AF-MSCs decrease bowel inflammation, increase cell
[26]
[25]

g


Table 2 Functions and applications of stem cells in NEC (Continued)

\begin{tabular}{|c|c|c|c|c|c|c|c|}
\hline $\begin{array}{l}\text { Stem } \\
\text { cell } \\
\text { type }\end{array}$ & $\begin{array}{l}\text { Stem cell } \\
\text { origin }\end{array}$ & $\begin{array}{l}\text { Stem cell } \\
\text { administration }\end{array}$ & Model & Modeling method $^{\mathrm{a}}$ & Main findings & Mechanism & Reference \\
\hline & & & & & $\begin{array}{l}\text { proliferation and reduce cell } \\
\text { apoptosis. } \\
\text { AF-MSCs mediated effects do not } \\
\text { depend on direct repopulation, but } \\
\text { on a paracrine manner. }\end{array}$ & & \\
\hline $\begin{array}{l}\text { AF- } \\
\text { MSC }\end{array}$ & E14 rat & $\begin{array}{l}\text { Intraperitoneal } \\
\text { injection }\end{array}$ & In vivo & $\begin{array}{l}\text { Rat pups with hyperosmolar } \\
\text { formula, hypoxia ( } 5 \% \mathrm{O}_{2}, 95 \% \mathrm{~N}_{2} \\
10 \text { min, tid for } 2 \text { days), and LPS (4 } \\
\mathrm{mg} / \mathrm{kg} \text {, qd for } 2 \text { days) }\end{array}$ & $\begin{array}{l}\text { AF-MSCs decrease fluid retention } \\
\text { and lower the incidence of ascites } \\
\text { in NEC rats. }\end{array}$ & & {$[27]$} \\
\hline $\begin{array}{l}\text { AF- } \\
\text { MSC }\end{array}$ & E14.5 rat & $\begin{array}{l}\text { Intraperitoneal } \\
\text { injection }\end{array}$ & In vivo & $\begin{array}{l}\text { Rat pups with formula, hypoxia } \\
\left(100 \% \mathrm{~N}_{2}, 1.5 \mathrm{~min} \text {, tid for } 4 \text { days) }\right. \\
\text { and hypothermia ( } 4{ }^{\circ} \mathrm{C}, 10 \mathrm{~min} \text {, tid } \\
\text { for } 4 \text { days) }\end{array}$ & $\begin{array}{l}\text { BM-MSC, AF-MSC, amniotic fluid- } \\
\text { derived NSC and enteric NSC treat- } \\
\text { ments all show significant reduc- } \\
\text { tions in NEC incidence compared } \\
\text { to the control group. } \\
\text { There is no significant difference in } \\
\text { incidence among the four } \\
\text { treatment groups. }\end{array}$ & / & [24] \\
\hline $\begin{array}{l}\text { AF- } \\
\text { MSC }\end{array}$ & E14.5 rat & $\begin{array}{l}\text { Intraperitoneal } \\
\text { injection }\end{array}$ & In vivo & $\begin{array}{l}\text { Rat pups with formula, hypoxia } \\
\left(100 \% \mathrm{~N}_{2}, 1.5 \mathrm{~min} \text {, tid for } 4 \text { days) }\right. \\
\text { and hypothermia ( } 4{ }^{\circ} \mathrm{C}, 10 \mathrm{~min} \text {, tid } \\
\text { for } 4 \text { days) }\end{array}$ & $\begin{array}{l}\text { BM-MSC, AF-MSC, amniotic fluid- } \\
\text { derived NSC, and enteric NSC treat- } \\
\text { ments all show a significant de- } \\
\text { crease in intestinal permeability } \\
\text { and improved gut barrier function } \\
\text { compared to the control group. } \\
\text { There is no significant difference in } \\
\text { intestinal permeability or gut } \\
\text { barrier function among the four } \\
\text { treatment groups. }\end{array}$ & / & [23] \\
\hline $\begin{array}{l}\text { AF- } \\
\text { MSC }\end{array}$ & Mouse pup & $\begin{array}{l}\text { Intraperitoneal } \\
\text { injection }\end{array}$ & $\begin{array}{l}\text { In vivo } \\
\text { Ex } \\
\text { vivo }\end{array}$ & $\begin{array}{l}\text { Mouse pup with formula, exposure } \\
\text { to hypoxia for } 4 \text { days and oral LPS } \\
\text { injection ( } 4 \mathrm{mg} / \mathrm{kg} \text { for } 2 \text { days) }\end{array}$ & $\begin{array}{l}\text { AF-MSC rescues intestinal injury, } \\
\text { restores epithelial regeneration, and } \\
\text { increases active ISCs. }\end{array}$ & Wnt & {$[28]$} \\
\hline \multicolumn{8}{|c|}{ Umbilical cord-derived mesenchymal stem cells (UC-MSC) } \\
\hline $\begin{array}{l}\text { UC- } \\
\text { MSC }\end{array}$ & Human & $\begin{array}{l}\text { Intraperitoneal } \\
\text { injection }\end{array}$ & $\begin{array}{l}\text { In } \\
\text { vitro } \\
\text { In vivo }\end{array}$ & $\begin{array}{l}\text { Rat pups with formula gavage } \\
\text { (supplemented with } 8 \mathrm{mg} / \mathrm{kg} \mathrm{LPS}) \text {, } \\
\text { hypoxia }\left(5 \% \mathrm{O}_{2}, 95 \% \mathrm{~N}_{2}, 10 \mathrm{~min},\right. \\
\text { tid), and hypothermia }\left(4{ }^{\circ} \mathrm{C}, 10\right. \\
\text { min, bid) }\end{array}$ & $\begin{array}{l}\text { UC-MSCs exert beneficial effects in } \\
\text { NEC via the production of the } \\
\text { paracrine mediator } \mathrm{H}_{2} \mathrm{~S} \text {. } \\
\text { UC-MSCs produce more } \mathrm{H}_{2} \mathrm{~S} \text { under } \\
\text { hypoxic conditions. }\end{array}$ & $\mathrm{H}_{2} \mathrm{~S}$ & [29] \\
\hline \multicolumn{8}{|c|}{ Neural stem cell (NSC) } \\
\hline NSC & $\begin{array}{l}\text { Mouse } \\
\text { embryos at } \\
12.5 \text { days } \\
\text { post coitum }\end{array}$ & $\begin{array}{l}\text { Intraperitoneal } \\
\text { injection }\end{array}$ & In vivo & $\begin{array}{l}\text { Rat pups with hypertonic formula, } \\
\text { hypoxia ( } 100 \% \mathrm{~N}_{2}, 1 \mathrm{~min} \text {, bid for } 3 \\
\text { days), hypothermia ( } 4{ }^{\circ} \mathrm{C}, 10 \mathrm{~min}, \\
\text { bid for } 3 \text { days), and LPS ( } 2 \mathrm{mg} / \mathrm{kg} \text {, } \\
8 \mathrm{~h} \text { after birth) }\end{array}$ & $\begin{array}{l}\text { Myenteric plexus ganglia are } \\
\text { damaged in NEC patients. } \\
\text { NSC transplantation improves the } \\
\text { enteric nervous system, intestinal } \\
\text { integrity, stem cell differentiation, } \\
\text { and intestinal transit, as well as } \\
\text { decreases the mortality of NEC rats. }\end{array}$ & / & {$[30]$} \\
\hline NSC & E11.5 mouse & $\begin{array}{l}\text { Intraperitoneal } \\
\text { injection }\end{array}$ & $\begin{array}{l}\text { In } \\
\text { vitro } \\
\text { In vivo }\end{array}$ & $\begin{array}{l}\text { Mouse pups with formula, hypoxia } \\
\text { ( } 100 \% \mathrm{~N}_{2}, 1 \mathrm{~min} \text {, bid for } 3 \text { days) } \\
\text { and hypothermia ( } 4{ }^{\circ} \mathrm{C}, 10 \mathrm{~min} \text {, bid } \\
\text { for } 3 \text { days) }\end{array}$ & $\begin{array}{l}\text { NSC transplantation reduces NEC } \\
\text { incidence. } \\
\text { NSC injection improves gut barrier } \\
\text { function and intestinal motility. } \\
\text { NSC-HB-EGF co-administration or } \\
\text { HB-EGF-overexpressed NSC has } \\
\text { augmented therapeutic effects on } \\
\text { NEC. }\end{array}$ & / & {$[31]$} \\
\hline $\begin{array}{l}\text { AF- } \\
\text { NSC }\end{array}$ & E14.5 rat & $\begin{array}{l}\text { Intraperitoneal } \\
\text { injection }\end{array}$ & In vivo & $\begin{array}{l}\text { Rat pups with formula, hypoxia } \\
\left(100 \% \mathrm{~N}_{2}, 1.5 \mathrm{~min} \text {, tid for } 4 \text { days }\right)\end{array}$ & $\begin{array}{l}\text { BM-MSC, AF-MSC, amniotic fluid- } \\
\text { derived NSC, and enteric NSC treat- }\end{array}$ & / & {$[24]$} \\
\hline $\begin{array}{l}\text { E- } \\
\text { NSC }\end{array}$ & Rat pup & & & $\begin{array}{l}\text { and hypothermia }\left(4^{\circ} \mathrm{C} \text {, } 10 \mathrm{~min} \text {, tid }\right. \\
\text { for } 4 \text { days) }\end{array}$ & $\begin{array}{l}\text { ments all show significant reduc- } \\
\text { tions in NEC incidence compared } \\
\text { to the control group. } \\
\text { There is no significant difference in } \\
\text { incidence among the four } \\
\text { treatment groups. }\end{array}$ & & \\
\hline
\end{tabular}


Table 2 Functions and applications of stem cells in NEC (Continued)

\begin{tabular}{|c|c|c|c|c|c|c|c|}
\hline $\begin{array}{l}\text { Stem } \\
\text { cell } \\
\text { type }\end{array}$ & $\begin{array}{l}\text { Stem cell } \\
\text { origin }\end{array}$ & $\begin{array}{l}\text { Stem cell } \\
\text { administration }\end{array}$ & Model & Modeling method ${ }^{a}$ & Main findings & Mechanism & Reference \\
\hline $\begin{array}{l}\text { AF- } \\
\text { NSC }\end{array}$ & E14.5 rat & $\begin{array}{l}\text { Intraperitoneal } \\
\text { injection }\end{array}$ & In vivo & \multirow{2}{*}{$\begin{array}{l}\text { Rat pups with formula, hypoxia } \\
\left(100 \% \mathrm{~N}_{2}, 1.5 \mathrm{~min} \text {, tid for } 4 \text { days) }\right. \\
\text { and hypothermia ( } 4{ }^{\circ} \mathrm{C}, 10 \mathrm{~min} \text {, tid } \\
\text { for } 4 \text { days) }\end{array}$} & \multirow{2}{*}{$\begin{array}{l}\text { BM-MSC, AF-MSC, amniotic fluid- } \\
\text { derived NSC, and enteric NSC treat- } \\
\text { ments all show a significant de- } \\
\text { crease in intestinal permeability } \\
\text { and improved gut barrier function } \\
\text { compared to the control group. } \\
\text { There is no significant difference in } \\
\text { intestinal permeability or gut } \\
\text { barrier function among the four } \\
\text { treatment groups. }\end{array}$} & \multirow[t]{2}{*}{ / } & \multirow[t]{2}{*}{ [23] } \\
\hline $\begin{array}{l}\text { E- } \\
\text { NSC }\end{array}$ & Rat pup & & & & & & \\
\hline NSC & / & / & $\begin{array}{l}\text { In } \\
\text { vitro } \\
\text { In vivo }\end{array}$ & $\begin{array}{l}\text { Rat pups with formula, hypoxia } \\
\left(100 \% \mathrm{~N}_{2}, 1 \mathrm{~min} \text {, bid for } 4 \text { days) }\right. \\
\text { and hypothermia ( } 4{ }^{\circ} \mathrm{C}, 10 \mathrm{~min} \text {, bid } \\
\text { for } 4 \text { days) }\end{array}$ & $\begin{array}{l}\text { NSC differentiation in ENC rats is } \\
\text { increased by HB-EGF. } \\
\text { NSC expression of nNOS is } \\
\text { enhanced by HB-EGF. }\end{array}$ & / & [32] \\
\hline
\end{tabular}

${ }^{a}$ Modeling methods for in vivo studies

conditioned media lacks therapeutic potency, probably due to insufficient release and subsequent degradation. In contrast, the application of prolyl hydroxylase 2 (PHD2)-silenced BM-MSC-conditioned media achieves therapeutic effects in NEC rats [25]. Mechanistically, the BM-MSC-mediated paracrine effects on relieving NEC are contributed by nuclear factor- $\kappa B$ (NF- $\kappa B$ ) signaling, and the silencing of PHD2 in BM-MSCs enhances NF$\kappa \mathrm{B}$ activation, which further increases the paracrine release of insulin-like growth factor (IGF)-1 and transforming growth factor-beta 2 (TGF- $\beta 2$ ) to reduce intestinal injury [25].

Several failures have been reported referring to the use of BM-MSCs in animal models. Zani et al. attempt to intravenously inject BM-MSCs into NEC rats; however, they do not demonstrate improved survival compared to rats injected with PBS [26]. Fetus suffering from hypoxia-ischemia is under high risk of intestinal injury and developing NEC. Preterm fetal sheep exposed to umbilical cord occlusion, which induces hypoxicischemic events, receive BM-MSC administration intravenously but do not show attenuation in intestinal injury [22]. These frustrating results inspire researchers to explore the role of other types of stem cells in NEC therapy.

\section{Amniotic fluid-derived mesenchymal stem cells}

Since amniotic fluid also contains plenty of stem cells and is conveniently collected during amniocentesis, researchers have focused on amniotic fluid-derived mesenchymal stem cells (AF-MSCs). Good et al. first show that amniotic fluid microinjection into the fetal intestine reduces the severity of NEC in mice models, indicating that amniotic fluid, presumably the AF-MSCs contained inside, can enhance the healing of NEC $[26,34]$. In a preterm porcine NEC model, AF administration during both the total parenteral nutrition and enteral nutrition periods increases the gain of body weight and improves the NEC scores [35]. Intraperitoneal injection of AFMSCs is further performed, and macroscopic gut damage, intestinal function, bowel inflammation, as well as enterocyte proliferation in NEC rats are improved [26]. The improved survival and enhanced repair by AFMSCs are primarily achieved by paracrine manner, more specifically, the stromal cells expressing cyclooxygenase 2 (COX-2), rather than direct repopulation of injured cells [26]. In clinical practice, neonates with NEC often develop ascites due to fluid retention, which is also a feature in the modified Bell's NEC staging criteria [36]. AFMSCs by intraperitoneal injection are shown to significantly decrease fluid retention and the incidence of ascites in NEC rats [27]. The epithelial regeneration and activation of ISCs are rescued by AF-MSCs administered intraperitoneally in NEC mice via activation of the Wnt signaling [28].

\section{Umbilical cord-derived mesenchymal stem cells}

Similar to amniotic fluid, umbilical blood is rich in stem and progenitor cells, and umbilical cord-derived mesenchymal stem cells (UC-MSCs) are easily accessible with low immunogenicity [37]. The intraperitoneal injection of UC-MSCs exerts beneficial effects in protecting intestines from injury in experimental NEC [29]. Paracrine release of hydrogen sulfide $\left(\mathrm{H}_{2} \mathrm{~S}\right)$, which confers cytoprotective, antioxidant, and anti-inflammatory functions at low levels, is increased in UC-MSCs under hypoxic conditions, and contributes to the protection of intestine.

\section{Other types of mesenchymal stem cells}

The research on other types of MSCs, for example, MSCs derived from ESCs or iPSCs, is still insufficient in the field of NEC treatment. Ethical limitations exist for ESCs since it involves the destruction of human 
embryos, and there are fewer ethical concerns associated with iPSCs because they are directly reprogrammed from adult cells [38]. Recently, Kagia et al. compare the intraperitoneal administration of BM-MSCs, UC-MSCs, ESC-MSCs, and iPSC-MSCs in a chemically induced acute enterocolitis model, resembling NEC histopathologically [39]. In this model, the prolongation of survival in mice by BM-MSC or UC-MSC injection is greater than that by ESC-MSC or iPSC-MSC injection [39]. Furthermore, the clinical and histopathological improvement is only seen in mice under BM-MSC and UC-MSC treatment [39].

\section{Neural stem cells (NSCs)}

The enteric nervous system (ENS), which is able to control gastrointestinal function without input from the brain or spinal cord, is the largest and most complex division of the peripheral nervous system [40]. Newborns have an immature ENS, which is vulnerable to injury and may predispose them to NEC. Newborns with NEC demonstrate a noticeable reduction in neuronal and glial cells within myenteric plexus and external submucosal plexus. NSCs are responsible for the repair and renewal of neurons in ENS, and therefore draw researchers' attention into this field [41].

Zhou et al. first report the use of NSC injection for NEC therapy, and rat pups receiving NSC transplantation demonstrate increased enteric nervous system integrity, stem cell differentiation, intestinal transit, and survival [30]. NSC transplantation in a mouse model also shows improved gut barrier function and intestinal motility, with decreased NEC incidence [31]. Similar to the beneficial effects of HB-EGF on BM-MSC administration, HB-EGF enhances the proliferation and decreases the apoptosis of NSCs in vitro, and the simultaneous administration of HB-EGF and NSCs in vivo results in decreased intestinal injury scores and improved gut barrier function as well as increased motility by the protection of neurons [31]. HB-GEF also increases NSC differentiation and the expression of neuronal nitric oxide synthase (nNOS), which enhances NO production and protects neurons from degeneration or damage [32].

For clinical practice, the acquisition of NSCs from fetal guts is not practical, and therefore NSCs collected from amniotic fluid can be an alternative for NEC therapy $[30,42]$. With the use of amniotic fluid-derived NSCs (AF-NSCs), the incidence and severity of NEC in rats are significantly reduced, and the reduction in NEC incidence were not significantly different compared to that in the enteric NSC (E-NSC) treatment group, BM-MSC treatment group or AF-MSC treatment group, indicating that different types of stem cells might be equivalently effective for NEC treatment under certain biological conditions [24]. Subsequently, the effects of BM-MSCs,
AF-MSCs, AF-NSCs, and E-NSCs in improving gut barrier function are evaluated. In spite of the results that the four types of stem cells demonstrate no difference in the capacity to decrease intestinal permeability and improve gut barrier functions, amniotic fluid-derived stem cells are preferred for use because they are easily acquired and cultured [23].

\section{Exosomes in necrotizing enterocolitis therapy (Table 3)}

Although an increasing number of studies have provided evidence that stem cell treatment is beneficial for NEC, several concerns are raised in terms of stem cell therapy. Stem cells can potentially and unexpectedly trigger the immune response. In addition, the acquisition and culture of stem cells are challenging and may bring about ethical issues [11]. Therefore, a potent therapeutic strategy without the direct involvement of stem cells is needed. Inspired by the fact that exosomes with considerable therapeutic efficacy can be derived from most types of cells, including stem cells, researchers consider exosomes as attractive candidates for the NEC therapy.

\section{Stem cell-derived exosomes}

As described above, stem cells decrease the incidence of NEC in animal models, mainly by a paracrine manner, and therefore the application of stem cell-derived exosomes (SC-Exs), as bioactive factors secreted by stem cells, achieves similar or better protective effects [44]. Rager et al. isolate exosomes from BM-MSCs, and the exposure to BM-MSC-derived exosomes (BM-MSC-Exs) enhances intestinal epithelial cell wound healing in vitro, while the exposure to BM-MSC-conditioned media without exosomes abrogates the wound healing rate [43]. Intraperitoneal injection of BM-MSC-Exs preserves the gut barrier integrity, and reduces the incidence and severity of NEC in rats $[43,44]$.

Exosomes derived from other types of stem cells, including AF-MSCs, AF-NSCs, and E-NSCs are further compared to evaluate their therapeutic effects. It is shown that BM-MSC-Exs, AF-MSC-derived exosomes (AF-MSC-Exs), AF-NSC-derived exosomes (AF-NSCExs), and E-NSC-derived exosomes (E-NSC-Exs) have equivalent effects of improving gut barrier function and reducing NEC incidences in rats [44]. Mechanistically, AF-MSC-Exs have been identified to improve NECinduced intestinal regeneration by the Wnt signaling [28].

\section{Human breast milk-derived exosomes}

Exosomes are not only released by stem cells, but also present in body fluids, for instance, breast milk. Breast milk is naturally rich in exosomes and can be obtained from the lactating mother or all lactating women, which 
Table 3 Functions and applications of exosomes in NEC

\begin{tabular}{|c|c|c|c|c|c|c|c|c|c|}
\hline $\begin{array}{l}\text { Exosome } \\
\text { type }\end{array}$ & $\begin{array}{l}\text { Exosome } \\
\text { origin }\end{array}$ & $\begin{array}{l}\text { Exosome } \\
\text { isolation }\end{array}$ & $\begin{array}{l}\text { Exosome } \\
\text { concentration }\end{array}$ & $\begin{array}{l}\text { Exosome } \\
\text { administration }\end{array}$ & Model & $\begin{array}{l}\text { Modeling } \\
\text { method }^{\mathrm{a}}\end{array}$ & Main findings & Mechanism & Reference \\
\hline $\begin{array}{l}\text { AF-MSC- } \\
\text { Ex }\end{array}$ & Rat & $\begin{array}{l}\text { ExoQuick } \\
\text { reagent }\end{array}$ & 1 & $\begin{array}{l}\text { Intraperitoneal } \\
\text { injection }\end{array}$ & $\begin{array}{l}\text { In } \\
\text { vitro } \\
\text { In vivo } \\
\text { Ex } \\
\text { vivo }\end{array}$ & $\begin{array}{l}\text { Mouse pup with } \\
\text { formula, } \\
\text { exposure to } \\
\text { hypoxia for } 4 \\
\text { days and oral } \\
\text { LPS injection (4 } \\
\text { mg/kg for } 2 \\
\text { days) }\end{array}$ & $\begin{array}{l}\text { AF-MSC-Exs } \\
\text { increase cellular } \\
\text { proliferation, } \\
\text { reduce } \\
\text { inflammation, and } \\
\text { regenerate a } \\
\text { normal } \\
\text { epithelium. } \\
\text { AF-MSC-Exs } \\
\text { attenuate NEC } \\
\text { intestinal injury via } \\
\text { activating the Wnt } \\
\text { signaling pathway. }\end{array}$ & $\begin{array}{l}\text { Wnt/ß- } \\
\text { catenin (ISCs) }\end{array}$ & {$[28]$} \\
\hline $\begin{array}{l}\text { BM-MSC- } \\
\text { Ex }\end{array}$ & Mouse & $\begin{array}{l}\text { Serial } \\
\text { centrifugation } \\
\text { (in vitro) } \\
\text { PureExo } \\
\text { Exosome } \\
\text { Isolation kit } \\
\text { (in vivo) }\end{array}$ & $\begin{array}{l}\sim 2.5 \times 10^{9} \\
\text { exosomes } / 50 \\
\mu \mathrm{L}\end{array}$ & $\begin{array}{l}\text { Intraperitoneal } \\
\text { injection }\end{array}$ & $\begin{array}{l}\text { In } \\
\text { vitro } \\
\text { In vivo }\end{array}$ & $\begin{array}{l}\text { Mouse pup with } \\
\text { formula, hypoxia } \\
\left(100 \% \mathrm{~N}_{2}, 1.5\right. \\
\text { min, bid for } 4 \\
\text { days) and } \\
\text { hypothermia (4 } \\
{ }^{\circ} \mathrm{C}, 10 \text { min, bid } \\
\text { for } 4 \text { days) }\end{array}$ & $\begin{array}{l}\text { BM-MSC-Exs } \\
\text { increase wound } \\
\text { healing in vitro. } \\
\text { BM-MSC-Exs } \\
\text { significantly lower } \\
\text { gut permeability } \\
\text { and the incidence } \\
\text { of NEC in vivo. }\end{array}$ & / & [43] \\
\hline $\begin{array}{l}\text { AF-MSC- } \\
\text { Ex }\end{array}$ & Rat & $\begin{array}{l}\text { Ultra- } \\
\text { centrifugation }\end{array}$ & $\begin{array}{l}4 \times 10^{8} \\
\text { exosomes/50 }\end{array}$ & $\begin{array}{l}\text { Intraperitoneal } \\
\text { injection }\end{array}$ & In vivo & $\begin{array}{l}\text { Rat pups with } \\
\text { formula, hypoxia }\end{array}$ & $\begin{array}{l}\text { BM-MSC-EXs, AF- } \\
\text { MSC-Exs, amniotic }\end{array}$ & / & [44] \\
\hline $\begin{array}{l}\text { BM-MSC- } \\
\text { Ex }\end{array}$ & & & & & & $\begin{array}{l}\left(100 \% \mathrm{~N}_{2}, 1.5\right. \\
\text { min, tid for } 4 \\
\text { days) and }\end{array}$ & $\begin{array}{l}\text { fluid-derived NSC- } \\
\text { Exs and enteric } \\
\text { NSC-Exs demon- }\end{array}$ & & \\
\hline $\begin{array}{l}\text { NSC-Ex } \\
\text { (amniotic } \\
\text { fluid- } \\
\text { derived) }\end{array}$ & & & & & & $\begin{array}{l}\text { hypothermia ( } 4 \\
{ }^{\circ} \mathrm{C}, 10 \mathrm{~min} \text {, tid } \\
\text { for } 4 \text { days) }\end{array}$ & $\begin{array}{l}\text { strate equivalent } \\
\text { reductions in NEC } \\
\text { incidence. } \\
\text { Stem cell-derived }\end{array}$ & & \\
\hline $\begin{array}{l}\text { NSC-Ex } \\
\text { (enteric) }\end{array}$ & & & & & & & $\begin{array}{l}\text { exosomes are } \\
\text { equivalent to stem } \\
\text { cells in NEC } \\
\text { therapy. }\end{array}$ & & \\
\hline HM-Ex & Human & $\begin{array}{l}\text { Ultra- } \\
\text { centrifugation }\end{array}$ & $0-10 \mu \mathrm{g}$ & / & $\begin{array}{l}\text { In } \\
\text { vitro }\end{array}$ & / & $\begin{array}{l}\text { HM-Exs reduce } \\
\text { oxidative stress- } \\
\text { related injury on } \\
\text { intestinal epithelial } \\
\text { cells. }\end{array}$ & / & {$[45]$} \\
\hline HM-Ex & Human & $\begin{array}{l}\text { Serial } \\
\text { centrifugation }\end{array}$ & $0.1 \mu \mathrm{g} / \mu \mathrm{L}$ & / & $\begin{array}{l}\text { Ex } \\
\text { vivo }\end{array}$ & / & $\begin{array}{l}\text { HM-Exs derived } \\
\text { from colostrum, } \\
\text { transitional or } \\
\text { mature human } \\
\text { milk prevent } \\
\text { inflammatory } \\
\text { injury. } \\
\text { HM-Exs derived } \\
\text { from colostrum } \\
\text { are most effective } \\
\text { in decreasing } \\
\text { inflammatory } \\
\text { cytokine. }\end{array}$ & / & [46] \\
\hline HM-Ex & Human & $\begin{array}{l}\text { Ultra- } \\
\text { centrifugation }\end{array}$ & $200 \mu \mathrm{g} / \mathrm{mL}$ & Gavage & In vivo & $\begin{array}{l}\text { Rat pups with } \\
\text { formula and } \\
\text { hypoxia ( } 5 \% \mathrm{O}_{2} \text {, } \\
75 \% \mathrm{~N}_{2}, 5 \mathrm{~min}, \\
\text { bid for } 4 \text { days) }\end{array}$ & $\begin{array}{l}\text { HM-Exs promote } \\
\text { the proliferation } \\
\text { and migration of } \\
\text { intestinal epithelial } \\
\text { cells both in vitro } \\
\text { and in vivo. } \\
\text { Peptidomic } \\
\text { differences } \\
\text { between preterm } \\
\text { and term milk } \\
\text { exosomes are } \\
\text { revealed. }\end{array}$ & / & [47] \\
\hline
\end{tabular}


Table 3 Functions and applications of exosomes in NEC (Continued)

\begin{tabular}{|c|c|c|c|c|c|c|c|c|c|}
\hline $\begin{array}{l}\text { Exosome } \\
\text { type }\end{array}$ & $\begin{array}{l}\text { Exosome } \\
\text { origin }\end{array}$ & $\begin{array}{l}\text { Exosome } \\
\text { isolation }\end{array}$ & $\begin{array}{l}\text { Exosome } \\
\text { concentration }\end{array}$ & $\begin{array}{l}\text { Exosome } \\
\text { administration }\end{array}$ & Model & $\begin{array}{l}\text { Modeling } \\
\text { method }^{\mathrm{a}}\end{array}$ & Main findings & Mechanism & Reference \\
\hline HM-EX & Human & $\begin{array}{l}\text { Ultra- } \\
\text { centrifugation }\end{array}$ & $\begin{array}{l}0-1 \times 10^{8} \\
\text { exosomes/100 } \\
\mu \mathrm{L}\end{array}$ & $\begin{array}{l}\text { Intraperitoneal } \\
\text { injection } \\
\text { Gavage }\end{array}$ & $\begin{array}{l}\text { In } \\
\text { vitro } \\
\text { In vivo }\end{array}$ & $\begin{array}{l}\text { Rat pups with } \\
\text { formula, hypoxia } \\
\left(<1.5 \% \mathrm{O}_{2}, 1.5\right. \\
\text { min, tid for } 4 \\
\text { days), } \\
\text { hypothermia (4 } \\
{ }^{\circ} \mathrm{C}, 10 \mathrm{~min} \text {, tid } \\
\text { for } 4 \text { days) and } \\
\text { LPS (2 } \mathrm{mg} / \mathrm{kg} \text {, } \\
\text { day 1) }\end{array}$ & $\begin{array}{l}\text { HM-Exs increase } \\
\text { the proliferation } \\
\text { and decrease the } \\
\text { apoptosis of } \\
\text { intestinal epithelial } \\
\text { cells. } \\
\text { HM-Exs } \\
\text { administered } \\
\text { intraperitoneally or } \\
\text { enterally decrease } \\
\text { NEC incidence. } \\
\text { HM-Ex enteral } \\
\text { administration has } \\
\text { better effects. }\end{array}$ & 1 & [48] \\
\hline HM-Ex & Human & $\begin{array}{l}\text { Ultra- } \\
\text { centrifugation }\end{array}$ & $\begin{array}{l}1.15-1.19 \mathrm{~g} / \\
\mathrm{mL}\end{array}$ & Gavage & $\begin{array}{l}\text { Ex } \\
\text { vivo } \\
\text { In vivo }\end{array}$ & $\begin{array}{l}\text { Mouse pups } \\
\text { with formula, } \\
\text { hypoxia ( } 5 \% \mathrm{O}_{2} \\
10 \mathrm{~min} \text {, tid for } 5 \\
\text { days) and LPS ( } 4 \\
\mathrm{mg} / \mathrm{kg} \text {, qd for } 5 \\
\text { days) }\end{array}$ & $\begin{array}{l}\text { HM-Exs reduce } \\
\text { inflammation and } \\
\text { improve mucus } \\
\text { production } \\
\text { in vivo. } \\
\text { HM-Exs decrease } \\
\text { inflammation in } \\
\text { hypoxia and LPS- } \\
\text { treated intestinal } \\
\text { organoids. } \\
\text { Pasteurized HM- } \\
\text { Exs are as effective } \\
\text { as raw HM-Exs. }\end{array}$ & / & [49] \\
\hline HM-Ex & Human & $\begin{array}{l}\text { ExoQuick } \\
\text { reagent }\end{array}$ & $0.5 \mathrm{mg} / \mathrm{mL}$ & I & $\begin{array}{l}\text { In } \\
\text { vitro }\end{array}$ & / & $\begin{array}{l}\mathrm{HM} \text {-Exs upregulate } \\
\text { Wnt/ } \beta \text {-catenin } \\
\text { signaling in ISCs } \\
\text { and increase cell } \\
\text { viability under } \\
\mathrm{H}_{2} \mathrm{O}_{2} \text { exposure } \\
\text { compared to the } \\
\text { control group. }\end{array}$ & $\begin{array}{l}\text { Wnt/ß- } \\
\text { catenin (ISCs) }\end{array}$ & [50] \\
\hline PM-Ex & Pig & $\begin{array}{l}\text { Ultra- } \\
\text { centrifugation }\end{array}$ & $0.037 \mathrm{mg} / \mu \mathrm{L}$ & Gavage & $\begin{array}{l}\text { In } \\
\text { vitro } \\
\text { In vivo }\end{array}$ & $\begin{array}{l}\text { Mouse pups } \\
\text { with LPS ( } 7.5 \\
\mathrm{mg} / \mathrm{kg} \text {, qd for } 7 \\
\text { days) }\end{array}$ & $\begin{array}{l}\text { PM-Exs inhibit } \\
\text { intestinal epithelial } \\
\text { cell apoptosis and } \\
\text { decrease TLR4/NF- } \\
\text { KB signaling } \\
\text { through miRNAs } \\
\text { in vitro. } \\
\text { PM-Exs prevent } \\
\text { LPS-induced intes- } \\
\text { tinal injury and in- } \\
\text { flammation } \\
\text { in vivo. }\end{array}$ & $\begin{array}{l}\text { miRNAs (miR- } \\
4334,-219 \\
-338)\end{array}$ & [51] \\
\hline BovM-Ex & Cow & $\begin{array}{l}\text { Ultra- } \\
\text { centrifugation }\end{array}$ & $1 \mu \mathrm{g} / \mu \mathrm{L}$ & Gavage & $\begin{array}{l}\text { In } \\
\text { vitro } \\
\text { In vivo }\end{array}$ & $\begin{array}{l}\text { Mouse pups } \\
\text { with formula, } \\
\text { hypoxia }\left(5 \% \mathrm{O}_{2}\right. \\
10 \mathrm{~min} \text {, tid for } 5 \\
\text { days) and LPS ( } 4 \\
\mathrm{mg} / \mathrm{kg} \text {, day } 6 \\
\text { and } 7 \text { ) }\end{array}$ & $\begin{array}{l}\text { BovM-Exs } \\
\text { promote goblet } \\
\text { cell and } \\
\text { endoplasmic } \\
\text { reticulum } \\
\text { chaperone protein } \\
\text { expression both } \\
\text { in vitro and } \\
\text { in vivo, which } \\
\text { increases mucus } \\
\text { production and } \\
\text { protect the } \\
\text { intestine. }\end{array}$ & $\begin{array}{l}\text { TFF3, MUC2 } \\
\text { (goblet cell), } \\
\text { and GRP94 } \\
\text { (endoplasmic } \\
\text { reticulum) }\end{array}$ & [52] \\
\hline
\end{tabular}


can be a promising strategy with safety and costeffectiveness. Compared to mature milk, early milk such as colostrum contains a higher number of exosomes [53]. The onset of NEC is during the 2-3 weeks of life when the colostrum is no longer available, indicating the reduction of bioactive molecules in breast milk might contribute to the NEC development [52].

Martin et al. first show that human breast milkderived exosome (HM-Ex) administration protects cells from oxidative stress-induced intestinal cell injury [45]. Despite the differences in species, human exosomes are able to protect the intestinal epithelial cells of rat [45]. The effect of HM-Ex on treating NEC is further evaluated in the ex vivo organoid model, which mimics the natural microenvironment of the gut [46, 49]. In addition, researchers try to figure out the impact of lactation period on the therapeutic effects of HM-Exs. Administration of colostrum (day 1-5 postpartum), transitional (day 6-14 postpartum) and mature (day > 15 postpartum) HM-Exs all reduce inflammatory injury in the ex vivo model [46]. Among the three types of exosomes, colostrum-derived exosomes have the best capacity to hamper pro-inflammatory responses, indicating that colostrum is the optimal source of HM-Exs [46]. Moreover, in vivo NEC models are constructed, and the intraperitoneal or enteral administration of HM-Exs decreases NEC incidences in rat pups [47, 48]. Pathological examination of rat intestines reveals that HM-Exs protect the villous integrity from injury and restore cellular proliferation [47].

Milk exosomes exhibit ability to traverse human intestinal epithelial barrier and thus have potential to be administered enterally [54]. HM-Exs administered by the enteral route (p.o.) result in further reduction of NEC incidences compared to those administered intraperitoneally, which indicates that the enteral route is a better option for HM-Ex administration [48]. The mechanisms by which HM-Exs reduce NEC incidences are partially contributed by activation of the $\mathrm{Wnt} / \beta$-catenin signaling pathway, which increases ISC viability and protects cells from oxidative stress [50].

In clinical practice, Holder pasteurization $\left(62.5{ }^{\circ} \mathrm{C}\right.$ for $30 \mathrm{~min}$ ) is used to guarantee the microbiological safety of donor breast milk; nevertheless, this process may disrupt the benefits brought by HM-Exs [55]. Recently, it is confirmed that both raw and pasteurized HM-Exs decrease the inflammation in ex vivo and in vivo NEC models, and the pasteurized HM-Exs are as effective as the raw HM-Exs [49]. These inspiring preclinical results strongly support the application of HM-Exs clinically.

\section{Other mammals' breast milk-derived exosomes}

Except for breast milk-derived exosomes isolated from human, exosomes can also be isolated from other mammals, such as murine and bovine. Li et al. first identify that rat breast milk-derived exosomes (RM-Exs) increase the viability and proliferation of intestinal epithelial cells, as well as stem cell activity, which are promising for treating NEC [52]. Porcine milk-derived exosomes (PM-Exs) gavage suppresses intestinal damage and LPS-induced inflammation in mice [51]. In vitro, LPS-induced apoptosis and inflammation of intestinal epithelial cells are decreased by PM-Exs [51]. The cytoprotective effects are induced by TLR4/NF-KB signaling and apoptotic pathway suppression mediated by exosome microRNAs (miRNAs), suggesting that miRNAenriched exosomes can be used as a novel preventative strategy for NEC $[51,56]$.

Although RM-Exs and PM-Exs are restricted to experimental use due to limitations on their sources, bovine milk-derived exosomes (BovM-Exs) possess great potential to be used in clinical practice, especially when sufficient human breast milk is not available. To mimic the normal fashion of nutrient administration in neonates, BovM-Exs are added to formula and given to NEC mice through gavage feeding. The administration of BovM-Exs increases goblet cell expression markers trefoil factor 3 (TFF3) and mucin 2 (MUC2), as well as the expression of endoplasmic reticulum chaperone protein glucose-regulated protein 94 (GRP94) both in vitro and in vivo, which enhances mucus production and protects gut barrier function $[52,57,58]$.

\section{Conclusions and future directions}

NEC is a notorious disease threatening the lives of neonates and brings enormous health and economic burden to the society. Early and effective management of necrotizing enterocolitis can not only alleviates intestinal injury, but also reduce complications, for example, brain injury and cognitive impairment [59]. Therefore, novel therapeutic approaches for NEC are needed.

Stem cell research on NEC has progressed tremendously in the past decade, demonstrating that stem cells are effective in reducing inflammation, improving gut barrier function and maintaining intestinal function. Among the three main types of stem cells (ISCs, MSCs, NSCs) that are focused on by researchers, ISCs are well elucidated for their physiological roles, while MSCs and NSCs are well described for their therapeutic effects after administration. To be specific, the therapeutic effect of BM-MSCs for NEC remains controversial, while AF-MSCs are a relatively more appropriate choice for potential clinical application, because they are more easily obtainable and may offer superior beneficial effects than other types of MSCs [26].

Compared to stem cell transplantation, administration of exosomes possesses distinct superiority. Compared to exosomes derived from stem cells, exosomes derived 
from human milk can be more easily obtained and orally administrated. Exosomes derived from colostrum demonstrate the best effects, and the pasteurization of human milk does not attenuate their effects [55]. In addition to human milk, bovine milk serves as another source of exosomes, and the therapeutic effects of BovM-Exs to NEC have been confirmed in vivo. Therefore, milk-derived exosomes are a safe, convenient, and effective strategy for NEC therapy.

Optimization of therapeutic effects can be achieved by several strategies in stem cell and exosome therapy. Stem cell modifications, including genetic modification and preconditioning modification, have been applied to improve the therapeutic properties. Genetic modification through constructed gene cassettes, preconditioning modifications by biological factors both improve the migration, adhesion, and survival, as well as reduce the premature senescence of stem cells [60]. Integrating stem cells with natural or synthetic biomaterial scaffolds, which enhance cell viability, differentiation and therapeutic efficacy, is effective for stem cell transplantation [61].

Advances in nanoengineering show great promise for the targeted delivery of exosomes towards the injured intestine, optimizing the therapeutic effects of exosomes.
Anchor peptides with corresponding targets on exosomes enable direct loading of exosomes [62]. Magnetically modified exosomes are efficient for tissue-specific delivery, whereas they might be toxic due to magnetic nanoparticles [63]. Aptamer-mediated exosome delivery demonstrates easy operation, enhanced efficacy, and high cost-effectiveness, which have become a superior choice of targeted therapy [64]. Nevertheless, research on engineered exosomes is in its infancy, and no evidence on the application of nanoengineered exosomes in the NEC therapy has been reported. Because targeted exosome delivery is fast-developing and promising, their application in the treatment of NEC should be brought to the forefront.

To achieve the best therapeutic effects, understanding the molecular pathways of how stem cells and exosomes function in relieving NEC is essential (Fig. 1). Overlapping mechanisms currently identified in NEC pathogenesis and stem cell/exosome therapy strengthens the rationality of treatment with stem cells and exosomes. Stem cells exert their effects through a paracrine manner, including growth factors, cytokines, and exosomes. Exosomes can further modulate the signaling pathways in the cells of intestines, for example, goblet cells and ISCs, which are crucial for gut barrier function and

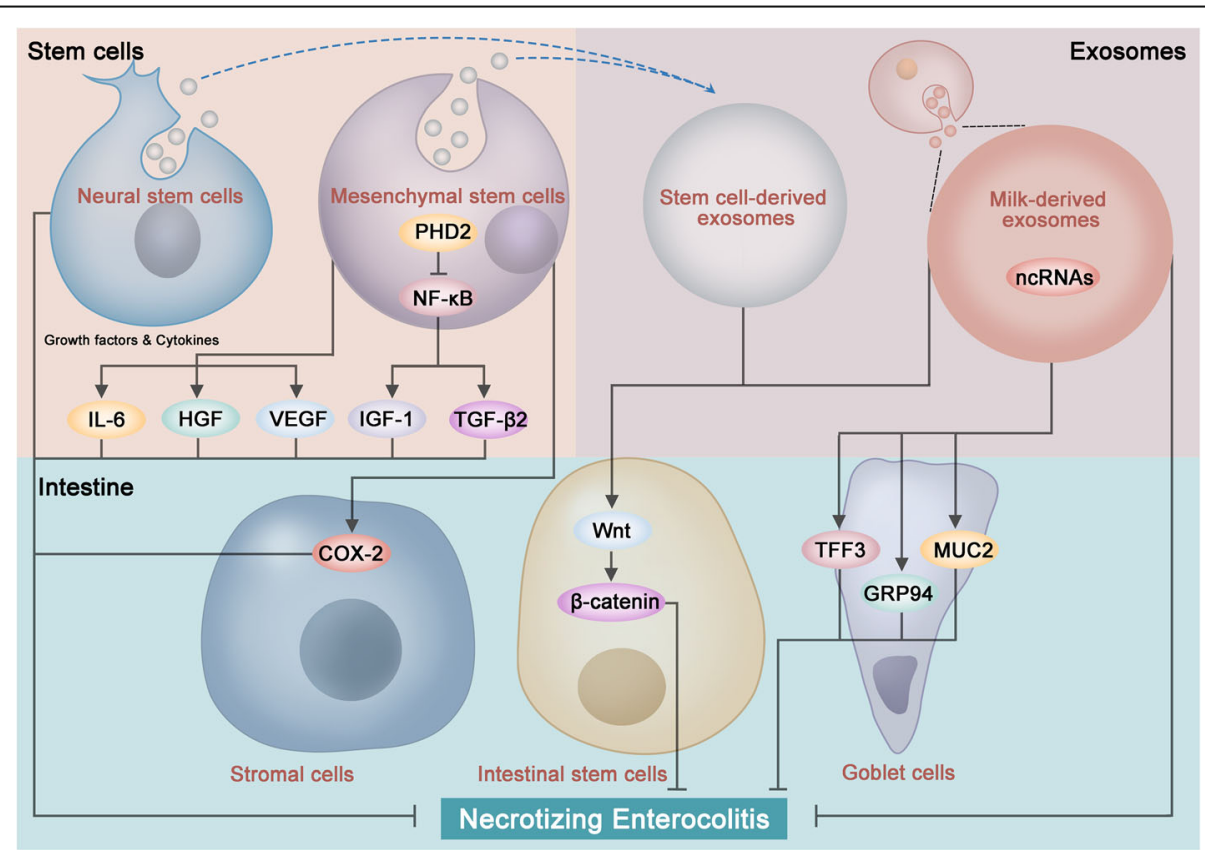

Fig. 1 Functions and mechanisms of stem cells and exosomes in necrotizing enterocolitis (NEC). Stem cells and exosomes exert beneficial effects to NEC via various signaling pathways. Mesenchymal stem cells (MSCS) secrete cytokines and growth factors including interleukin (IL)-6, vascular endothelial growth factor (VEGF), and hepatocyte growth factor (HGF). Downregulation of prolyl hydroxylase 2 (PHD2) activates the nuclear factor-KB (NF-KB) signaling in MSCs, which increases the paracrine release of insulin-like growth factor (IGF)-1 and transforming growth factor-beta 2 (TGF- $\beta 2$ ). MSCs increase the expression of cyclooxygenase 2 (COX-2) in stromal cells by the paracrine manner. Exosome (Exs) contains noncoding RNAs (ncRNAs) beneficial to NEC injury. Milk-derived Exs increase goblet cell expression markers trefoil factor 3 (TFF3) and mucin 2 (MUC2), as well as the expression of endoplasmic reticulum chaperone protein glucose-regulated protein 94 (GRP94). Both MSCs and MSCderived Exs can activate the Wnt/ $\beta$-catenin signaling pathway, which increases ISC viability and intestinal regeneration 
injury repair, partially via the non-coding RNAs (ncRNAs) inside. Current evidence indicates that stem cells and exosomes improve microcirculation, modulate immune responses, and alleviate inflammation $[65,66]$. The impaired Wnt signaling and ISC-mediated intestinal regeneration in the pathogenesis of NEC can be restored by both stem cells and exosomes. Despite these findings, the mechanisms remain largely unknown and can be further explored in the following aspects: (1) the most essential cytokines or growth factors can be identified; (2) more specific pathways associated with the therapeutic effects of stem cells and exosomes, particularly for those overlapping with the pathogenesis of NEC, can be explored; (3) the downstream pathways can be further confirmed in vivo; (4) omics research, including genomics, epigenomics, transcriptomics, proteomics, and metabolomics, can be performed; and (5) effects and mechanisms of stem cells and exosomes in improving complications of NEC can be assessed.

Recently, the application of stem cells in the NEC therapy clinically was reported. A 22-day old male baby received intravenous injection of UC-MSCs on the 4th day of surgery, and jejunostomy on the 46th day after surgery demonstrated remarkable improvement in intestinal blood supply, without the development of short bowel syndrome [67]. The case report is encouraging; however, the process of exosome isolation and purification remains to be improved. Rigorous clinical trials are needed to verify the safety, efficacy, and optimal usage of stem cells and exosomes for the NEC therapy (Fig. 2).

In conclusion, stem cells and exosomes, which have been demonstrated promising effects in both experimental and preclinical studies, are promising candidates for the NEC therapy. Further elucidation of mechanisms, improvements in preparation, bioengineering, and application, as well as rigorous clinical trials, will facilitate the application of stem cells and exosomes as novel strategies for pediatric diseases.

\section{Abbreviations}

AF-MSC: Amniotic fluid-derived mesenchymal stem cell; AF-NSC: Amniotic fluid-derived neutral stem cell; ASC: Adult stem cell; BM-MSC: Bone marrowderived mesenchymal stem cell; BovM-Ex: Bovine milk-derived exosome; COX-2: Cyclooxygenase 2; E-NSC: Enteric neural stem cell; EGF: Epidermal growth factor; ENS: Enteric nervous system; ESC: Embryonic stem cell; EV: Extracellular vesicle; Exs: Exosomes; GRP94: Glucose-regulated protein 94; H2S: Hydrogen sulfide; HB-EGF: Heparin-binding epidermal growth factor-like growth factor; HGF: Hepatocyte growth factor; HM-Ex: Human breast milkderived exosome; IGF: Insulin-like growth factor; IL: Interleukin; iPSC: Induced pluripotent stem cell; ISC: Intestinal stem cell; LPS: Lipopolysaccharide; miRNA: MicroRNA; MSC: Mesenchymal stem cell; MUC2: Mucin 2; ncRNA: Non-coding RNA; NEC: Necrotizing enterocolitis; NF-KB: Nuclear factor-KB; nNOS: Neuronal nitric oxide synthase; NSC: Neural stem cell; PHD2: Prolyl hydroxylase 2; PM-Ex: Porcine milk-derived exosome; RM-Ex: Rat breast milk-derived exosome; TFF3: Trefoil factor 3; TGF- $\beta 2$ : Transforming growth factor-beta 2; TLR: Toll-like receptor; UC-MSC: Umbilical cord-derived mesenchymal stem cell

\section{Acknowledgements}

The authors thank the funders listed in the "Funding" section for their support.

\section{Authors' contributions}

RZ and JW participated in the drafting and revision of the manuscript. ZZ, $Y L, W S$, and $H C$ participated in the revision of the manuscript. WS and $H C$ participated in the supervision of the manuscript and obtained funding. The authors read and approved the final manuscript.

\section{Funding}

This work is supported by the National Natural Science Foundation of China (grant No. 81300279, 81741067), the Natural Science Foundation for Distinguished Young Scholars of Guangdong Province (2021B1515020003),

Guangdong Province Natural Science Foundation (grant No.

2016A030313815, 2017A030313464), Science and Technology Planning

Project of Guangdong Province (grant No. 2015A020212029), Science and

Technology Program of Guangzhou (grant No. 201707010419 and

201804010050), and High-level Hospital Construction Project (grant No. DFJH201803 and KJ012019099).

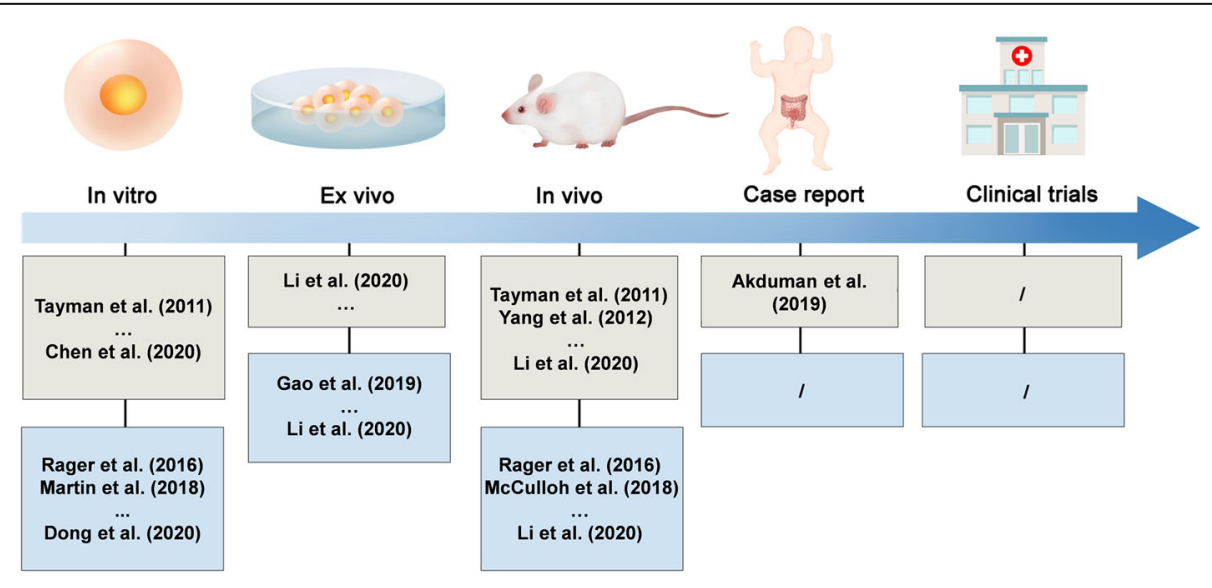

Research on stem cells

Fig. 2 Research progress in stem cells and exosomes for the necrotizing enterocolitis (NEC) treatment. Evidence has indicated the successful use of stem cells and exosomes in treating NEC. Rigorous clinical trials are needed for the application of stem cells and exosomes in the NEC therapy 


\section{Availability of data and materials}

Not applicable.

\section{Declarations}

Ethics approval and consent to participate

Not applicable.

\section{Consent for publication}

Not applicable.

\section{Competing interests}

The authors declare that they have no competing interests.

\section{Author details}

'Department of Gastroenterology, Guangdong Provincial People's Hospital, Guangdong Academy of Medical Sciences, Guangzhou 510080, China. ${ }^{2}$ Shantou University Medical College, Shantou 515041, China. ${ }^{3}$ Department of Hematology, Guangdong Provincial People's Hospital, Guangdong Academy of Medical Sciences, Guangzhou 510080, China.

Received: 10 March 2021 Accepted: 13 May 2021

Published online: 05 June 2021

\section{References}

1. Stoll BJ, Hansen NI, Bell EF, Walsh MC, Carlo WA, Shankaran S, et al. Trends in care practices, morbidity, and mortality of extremely preterm neonates, 1993-2012. JAMA. 2015;314(10):1039-51. https://doi.org/10.1001/jama.2015.1 0244

2. Clark RH, Gordon P, Walker WM, Laughon M, Smith PB, Spitzer AR. Characteristics of patients who die of necrotizing enterocolitis. J Perinatol. 2012;32(3):199-204. https://doi.org/10.1038/jp.2011.65.

3. Battarbee AN, Venkatesh KK, Aliaga S, Boggess KA. The association of pregestational and gestational diabetes with severe neonatal morbidity and mortality. J Perinatol. 2020;40(2):232-9. https://doi.org/10.1038/s41372-0190516-5.

4. Denning TL, Bhatia AM, Kane AF, Patel RM, Denning PW. Pathogenesis of NEC: role of the innate and adaptive immune response. Semin Perinatol. 2017:41(1):15-28. https://doi.org/10.1053/j.semperi.2016.09.014.

5. Koike Y, Li B, Ganji N, Zhu H, Miyake H, Chen Y, et al. Remote ischemic conditioning counteracts the intestinal damage of necrotizing enterocolitis by improving intestinal microcirculation. Nat Commun. 2020;11(1):4950. https://doi.org/10.1038/s41467-020-18750-9.

6. Schreurs R, Baumdick ME, Sagebiel AF, Kaufmann M, Mokry M, Klarenbeek $\mathrm{PL}$, et al. Human fetal TNF-a-cytokine-producing CD4(+) effector memory $T$ cells promote intestinal development and mediate inflammation early in life. Immunity. 2019;50(2):462-476.e468.

7. Cho SX, Rudloff I, Lao JC, Pang MA, Goldberg R, Bui CB, et al. Characterization of the pathoimmunology of necrotizing enterocolitis reveals novel therapeutic opportunities. Nat Commun. 2020;11(1):5794. https://doi.org/10.1038/s41467-020-19400-w

8. Hackam DJ, Sodhi CP. Toll-like receptor-mediated intestinal inflammatory imbalance in the pathogenesis of necrotizing enterocolitis. Cell Mol Gastroenterol Hepatol. 2018;6(2):229-238.e221

9. Li B, Lee C, Cadete M, Zhu H, Koike Y, Hock A, et al. Impaired Wnt/ß-catenin pathway leads to dysfunction of intestinal regeneration during necrotizing enterocolitis. Cell Death Dis. 2019;10(10):743. https://doi.org/10.1038/s41419019-1987-1.

10. Chagastelles PC, Nardi NB. Biology of stem cells: an overview. Kidney Int Suppl (2011). 2011;1((3):63-7.

11. Lo B, Parham L. Ethical issues in stem cell research. Endocr Rev. 2009;30(3): 204-13. https://doi.org/10.1210/er.2008-0031.

12. Santos AJM, Lo YH, Mah AT, Kuo CJ. The intestinal stem cell niche: homeostasis and adaptations. Trends Cell Biol. 2018;28(12):1062-78. https:// doi.org/10.1016/j.tcb.2018.08.001.

13. Yan KS, Chia LA, Li X, Ootani A, Su J, Lee JY, et al. The intestinal stem cell markers Bmi1 and Lgr5 identify two functionally distinct populations. Proc Natl Acad Sci U S A. 2012;109(2):466-71. https://doi.org/10.1073/pnas.111 8857109.

14. Yang J, Watkins D, Chen CL, Bhushan B, Zhou Y, Besner GE. Heparin-binding epidermal growth factor-like growth factor and mesenchymal stem cells act synergistically to prevent experimental necrotizing enterocolitis. J Am Coll Surg. 2012:215(4):534-45. https://doi.org/10.1016/j.jamcollsurg.2012.05.037.

15. Niño DF, Sodhi CP, Egan CE, Zhou Q, Lin J, Lu P, et al. Retinoic acid improves incidence and severity of necrotizing enterocolitis by lymphocyte balance restitution and repopulation of LGR5+ intestinal stem cells. Shock. 2017:47(1):22-32. https://doi.org/10.1097/SHK.0000000000000713.

16. Hong SN, Dunn JC, Stelzner M, Martín MG. Concise review: the potential use of intestinal stem cells to treat patients with intestinal failure. Stem Cells Transl Med. 2017;6(2):666-76. https://doi.org/10.5966/sctm.2016-0153.

17. Panés J, García-Olmo D, Van Assche G, Colombel JF, Reinisch W, Baumgart DC, et al. Long-term efficacy and safety of stem cell therapy (Cx601) for complex perianal fistulas in patients with Crohn's disease. Gastroenterology. 2018:154(5):1334-1342.e1334.

18. Sajeesh S, Broekelman T, Mecham RP, Ramamurthi A. Stem cell derived extracellular vesicles for vascular elastic matrix regenerative repair. Acta Biomater. 2020;113:267-78. https://doi.org/10.1016/j.actbio.2020.07.002.

19. El Andaloussi S, Mäger I, Breakefield XO, Wood MJA. Extracellular vesicles: biology and emerging therapeutic opportunities. Nat Rev Drug Discov. 2013;12(5):347-57. https://doi.org/10.1038/nrd3978.

20. Nassar W, El-Ansary M, Sabry D, Mostafa MA, Fayad T, Kotb E, et al. Umbilica cord mesenchymal stem cells derived extracellular vesicles can safely ameliorate the progression of chronic kidney diseases. Biomater Res. 2016; 20(1):21. https://doi.org/10.1186/s40824-016-0068-0.

21. Tayman C, Uckan D, Kilic E, Ulus AT, Tonbul A, Murat Hirfanoglu I, et al. Mesenchymal stem cell therapy in necrotizing enterocolitis: a rat study. Pediatr Res. 2011;70(5):489-94. https://doi.org/10.1203/PDR.0b013e31822d7ef2.

22. Nikiforou M, Willburger $C$, de Jong AE, Kloosterboer N, Jellema RK, Ophelders D, et al. Global hypoxia-ischemia induced inflammation and structural changes in the preterm ovine gut which were not ameliorated by mesenchymal stem cell treatment. Mol Med. 2016;22(1):244-57. https://doi. org/10.2119/molmed.2015.00252

23. McCulloh CJ, Olson JK, Wang Y, Vu J, Gartner S, Besner GE. Evaluating the efficacy of different types of stem cells in preserving gut barrier function in necrotizing enterocolitis. J Surg Res. 2017;214:278-85. https://doi.org/10.101 6/j.jss.2017.03.026

24. McCulloh CJ, Olson JK, Zhou Y, Wang Y, Besner GE. Stem cells and necrotizing enterocolitis: a direct comparison of the efficacy of multiple types of stem cells. J Pediatr Surg. 2017:52(6):999-1005. https://doi.org/10.1 016/j.jpedsurg.2017.03.028.

25. Chen $H$, Zhang $H$, Zheng $Y$, Min $X$, Luo $Y$, Zhou W, et al. Prolyl hydroxylase 2 silencing enhances the paracrine effects of mesenchymal stem cells on necrotizing enterocolitis in an NF-KB-dependent mechanism. Cell Death Dis. 2020;11(3):188. https://doi.org/10.1038/s41419-020-2378-3.

26. Zani A, Cananzi M, Fascetti-Leon F, Lauriti G, Smith W, Bollini S, et al. Amniotic fluid stem cells improve survival and enhance repair of damaged intestine in necrotising enterocolitis via a COX-2 dependent mechanism. Gut. 2014;63(2):300-9. https://doi.org/10.1136/gutjnl-2012-303735.

27. Zani A, Cananzi M, Lauriti G, Fascetti-Leon F, Wells J, Siow B, et al. Amniotic fluid stem cells prevent development of ascites in a neonatal rat model of necrotizing enterocolitis. Eur J Pediatr Surg. 2014;24(1):57-60. https://doi. org/10.1055/s-0033-1350059.

28. Li B, Lee C, O'Connell JS, Antounians L, Ganji N, Alganabi M, et al. Activation of Wnt signaling by amniotic fluid stem cell-derived extracellular vesicles attenuates intestinal injury in experimental necrotizing enterocolitis. Cell Death Dis. 2020;11(9):750. https://doi.org/10.1038/s41419-020-02964-2.

29. Drucker NA, Te Winkel JP, Shelley WC, Olson KR, Markel TA. Inhibiting hydrogen sulfide production in umbilical stem cells reduces their protective effects during experimental necrotizing enterocolitis. J Pediatr Surg. 2019; 54(6):1168-73. https://doi.org/10.1016/j.jpedsurg.2019.02.037.

30. Zhou Y, Yang J, Watkins DJ, Boomer LA, Matthews MA, Su Y, et al. Enteric nervous system abnormalities are present in human necrotizing enterocolitis: potential neurotransplantation therapy. Stem Cell Res Ther. 2013;4(6):157. https://doi.org/10.1186/scrt387.

31. Wei J, Zhou Y, Besner GE. Heparin-binding EGF-like growth factor and enteric neural stem cell transplantation in the prevention of experimental necrotizing enterocolitis in mice. Pediatr Res. 2015:78(1):29-37. https://doi. org/10.1038/pr.2015.63.

32. Zhou Y, Wang Y, Olson J, Yang J Besner GE. Heparin-binding EGF-like growth factor promotes neuronal nitric oxide synthase expression and protects the enteric nervous system after necrotizing enterocolitis. Pediatr Res. 2017;82(3):490-500. https://doi.org/10.1038/pr.2017.68. 
33. Weil BR, Markel TA, Herrmann JL, Abarbanell AM, Meldrum DR. Mesenchymal stem cells enhance the viability and proliferation of human fetal intestinal epithelial cells following hypoxic injury via paracrine mechanisms. Surgery. 2009;146(2):190-7. https://doi.org/10.1016/.j.surg.2009. 03.031.

34. Good M, Siggers RH, Sodhi CP, Afrazi A, Alkhudari F, Egan CE, et al. Amniotic fluid inhibits Toll-like receptor 4 signaling in the fetal and neonatal intestinal epithelium. Proc Natl Acad Sci U S A. 2012;109(28):11330-5. https://doi.org/10.1073/pnas.1200856109.

35. Siggers J, Ostergaard MV, Siggers RH, Skovgaard K, Mølbak L, Thymann T, et al. Postnatal amniotic fluid intake reduces gut inflammatory responses and necrotizing enterocolitis in preterm neonates. Am J Physiol Gastrointest Liver Physiol. 2013;304(10):G864-75. https://doi.org/1 0.1152/ajpgi.00278.2012

36. Walsh MC, Kliegman RM. Necrotizing enterocolitis: treatment based on staging criteria. Pediatr Clin North Am. 1986;33(1):179-201. https://doi.org/1 0.1016/S0031-3955(16)34975-6.

37. De Chiara L, Famulari ES, Fagoonee S, van Daalen SKM, Buttiglieri S, Revelli $A$, et al. Characterization of human mesenchymal stem cells isolated from the testis. Stem Cells Int. 2018;2018:4910304.

38. Moradi S, Mahdizadeh H, Šarić T, Kim J, Harati J, Shahsavarani H, et al. Research and therapy with induced pluripotent stem cells (iPSCs): social, legal, and ethical considerations. Stem Cell Res Ther. 2019;10(1):341. https:// doi.org/10.1186/s13287-019-1455-y.

39. Kagia A, Tzetis M, Kanavakis E, Perrea D, Sfougataki I, Mertzanian A, et al. Therapeutic effects of mesenchymal stem cells derived from bone marrow, umbilical cord blood, and pluripotent stem cells in a mouse model of chemically induced inflammatory bowel disease. Inflammation. 2019;42(5): 1730-40. https://doi.org/10.1007/s10753-019-01033-x

40. Rao M, Gershon MD. Enteric nervous system development: what could possibly go wrong? Nat Rev Neurosci. 2018;19(9):552-65. https://doi.org/1 0.1038/s41583-018-0041-0.

41. Burns AJ, Thapar N. Neural stem cell therapies for enteric nervous system disorders. Nat Rev Gastroenterol Hepatol. 2014;11(5):317-28. https://doi. org/10.1038/nrgastro.2013.226.

42. Turner CG, Klein JD, Wang J, Thakor D, Benedict D, Ahmed A, et al. The amniotic fluid as a source of neural stem cells in the setting of experimental neural tube defects. Stem Cells Dev. 2013;22(4):548-53. https://doi.org/10.1 089/scd.2012.0215.

43. Rager TM, Olson JK, Zhou Y, Wang Y, Besner GE. Exosomes secreted from bone marrow-derived mesenchymal stem cells protect the intestines from experimental necrotizing enterocolitis. J Pediatr Surg. 2016;51(6):942-7. https://doi.org/10.1016/j.jpedsurg.2016.02.061.

44. McCulloh CJ, Olson JK, Wang Y, Zhou Y, Tengberg NH, Deshpande S, et al. Treatment of experimental necrotizing enterocolitis with stem cell-derived exosomes. J Pediatr Surg. 2018;53(6):1215-20. https://doi.org/10.1016/j. jpedsurg.2018.02.086.

45. Martin C, Patel M, Williams S, Arora H, Brawner K, Sims B. Human breast milk-derived exosomes attenuate cell death in intestinal epithelial cells. Innate Immun. 2018;24(5):278-84. https://doi.org/10.1177/175342591 8785715.

46. Gao R, Zhang R, Qian T, Peng X, He W, Zheng S, et al. A comparison of exosomes derived from different periods breast milk on protecting against intestinal organoid injury. Pediatr Surg Int. 2019;35(12):1363-8. https://doi. org/10.1007/s00383-019-04562-6.

47. Wang X, Yan X, Zhang L, Cai J, Zhou Y, Liu H, et al. Identification and peptidomic profiling of exosomes in preterm human milk: insights into necrotizing enterocolitis prevention. Mol Nutr Food Res. 2019;63(13): 1801247.

48. Pisano C, Galley J, Elbahrawy M, Wang Y, Farrell A, Brigstock D, et al. Human breast milk-derived extracellular vesicles in the protection against experimental necrotizing enterocolitis. J Pediatr Surg. 2020;55(1):54-8. https://doi.org/10.1016/j.jpedsurg.2019.09.052.

49. Miyake H, Lee C, Chusilp S, Bhalla M, Li B, Pitino M, et al. Human breast milk exosomes attenuate intestinal damage. Pediatr Surg Int. 2020;36(2):155-63. https://doi.org/10.1007/s00383-019-04599-7.

50. Dong P, Zhang Y, Yan DY, Wang Y, Xu X, Zhao YC, et al. Protective effects of human milk-derived exosomes on intestinal stem cells damaged by oxidative stress. Cell Transplant. 2020;29:963689720912690.

51. Xie MY, Hou LJ, Sun JJ, Zeng B, Xi QY, Luo JY, et al. Porcine milk exosome MiRNAs attenuate LPS-induced apoptosis through inhibiting TLR4/NF-KB and p53 pathways in intestinal epithelial cells. J Agric Food Chem. 2019; 67(34):9477-91. https://doi.org/10.1021/acs.jafc.9b02925.

52. Li B, Hock A, Wu RY, Minich A, Botts SR, Lee C, et al. Bovine milk-derived exosomes enhance goblet cell activity and prevent the development of experimental necrotizing enterocolitis. Plos One. 2019;14(1):e0211431. https://doi.org/10.1371/journal.pone.0211431.

53. Torregrosa Paredes P, Gutzeit C, Johansson S, Admyre C, Stenius F, Alm J, et al. Differences in exosome populations in human breast milk in relation to allergic sensitization and lifestyle. Allergy. 2014;69(4):463-71. https://doi. org/10.1111/all.12357.

54. Carobolante G, Mantaj J, Ferrari E, Vllasaliu D. Cow milk and intestinal epithelial cell-derived extracellular vesicles as systems for enhancing oral drug delivery. Pharmaceutics. 2020;12(3):226. https://doi.org/10.3390/pharma ceutics12030226.

55. Piemontese $\mathrm{P}$, Mallardi D, Liotto N, Tabasso C, Menis C, Perrone M, et al. Macronutrient content of pooled donor human milk before and after Holder pasteurization. BMC Pediatrics. 2019;19(1):58. https://doi.org/10.1186/ s12887-019-1427-5.

56. Xie MY, Chen T, Xi QY, Hou LJ, Luo JY, Zeng B, et al. Porcine milk exosome miRNAs protect intestinal epithelial cells against deoxynivalenol-induced damage. Biochem Pharmacol. 2020;175:113898. https://doi.org/10.1016/j. bcp.2020.113898.

57. Schroeder BO. Fight them or feed them: how the intestinal mucus layer manages the gut microbiota. Gastroenterology report. 2019;7(1):3-12. https://doi.org/10.1093/gastro/goy052.

58. Ghiasi SM, Dahlby T, Hede Andersen C, Haataja L, Petersen S, Omar-Hmeadi $\mathrm{M}$, et al. Endoplasmic reticulum chaperone glucose-regulated protein 94 is essential for proinsulin handling. Diabetes. 2019;68(4):747-60. https://doi. org/10.2337/db18-0671.

59. Zhou Q, Niño DF, Yamaguchi Y, Wang S, Fulton WB, Jia H, Lu P, Prindle T, Jr , Pamies D, Morris M et al: Necrotizing enterocolitis induces T lymphocytemediated injury in the developing mammalian brain. Sci Transl Med. 2021; 13(575):eaay6621.

60. Ocansey DKW, Pei B, Yan Y, Qian H, Zhang X, Xu W, et al. Improved therapeutics of modified mesenchymal stem cells: an update. J Transl Med. 2020;18(1):42. https://doi.org/10.1186/s12967-020-02234-x.

61. Willerth SM, Sakiyama-Elbert SE. Combining stem cells and biomaterial scaffolds for constructing tissues and cell delivery. Stem J. 2019;1(1):1-25. https://doi.org/10.3233/STJ-180001

62. Gao X, Ran N, Dong X, Zuo B, Yang R, Zhou Q, Moulton HM, Seow Y, Yin H: Anchor peptide captures, targets, and loads exosomes of diverse origins for diagnostics and therapy. Sci Transl Med. 2018;10(444):eaat0195.

63. Jiang Z, Shan K, Song J, Liu J, Rajendran S, Pugazhendhi A, et al. Toxic effects of magnetic nanoparticles on normal cells and organs. Life Sci. 2019; 220:156-61. https://doi.org/10.1016/j.lfs.2019.01.056.

64. Tran PH, Xiang D, Tran $\Pi$, Yin W, Zhang Y, Kong L, et al. Exosomes and nanoengineering: a match made for precision therapeutics. Adv Mater. 2020;32(18):1904040. https://doi.org/10.1002/adma.201904040.

65. Gu W, Hong X, Potter C, Qu A, Xu Q. Mesenchymal stem cells and vascular regeneration. Microcirculation. 2017;24(1):e12324.

66. Z Zhang H, Wang L, Li C, Yu Y, Yi Y, Wang J, et al. Exosome-induced regulation in inflammatory bowel disease. Front Immunol. 2019;10:1464. https://doi.org/10.3389/fimmu.2019.01464.

67. Akduman H, Dilli D, Ergün E, Çakmakçı E, Çelebi SK, Çitli R, et al. Successful mesenchymal stem cell application in supraventricular tachycardia-related necrotizing enterocolitis: a case report. Fetal Pediatr Pathol. 2019:1-6. https://doi.org/10.1080/15513815.2019.1693672.

\section{Publisher's Note}

Springer Nature remains neutral with regard to jurisdictional claims in published maps and institutional affiliations. 